\title{
RIGHT-SLIP OFFSET OF THE EOCENE BALLENA RIVER VALLEY ACROSS THE ELSINORE FAULT ZONE, SOUTHERN CALIFORNIA
}

\author{
by \\ Patrick L. Abbott \\ Ronald P. Kies \\ Dennis R. Kerr \\ Department of Geological Sciences \\ San Diego State University \\ San Diego, California 92182 \\ U. S. A.
}

\section{ABSTRACT}

Two small paleovalleys carved into granitic rocks of the Peninsular Ranges contain conglomerates similar to the Eocene Ballena Gravels farther west in San Diego County. These conglomerates are dominated by the distinctive, temporally restricted, Poway rhyolite clasts. The newly discovered fluvial conglomerates lie in the Vallecito Mountains east of the Elsinore fault zone. Extrapolation of the offset fluvial valley trends to the Elsinore fault suggests 37 kilometers ( 23 miles) of right slip.

\section{RESUMEN}

Dos valles pequeños paleolíticos, grabados en cuerpos graníticos de la Cordillera Peninsular, contienen conglomerados semejantes a las gravas de la Formación Ballena del Eoceno, localizada al oeste, en el Condado de San Diego. Este conglomerado es dominado por clastos riolíticos de la Formación Poway, los cuales son característicos y están temporalmente restringidos. Los conglomerados fluviales recientemente descubiertos, se encuentran en las Montañas del Vallecito, al este de la zona de la falla de Elsinore. Proyectando los rumbos de los conglomerados fluviales y de las gravas a través de la falla de Elsinore, se observa un desplazamien to de $37 \mathrm{~km}$. (23 millas) en un sentido lateral-derecho.

\section{INTRODUCTION}

The Ballena Gravels (actually conglomerate) were named by Fairbanks (1893) for a prominent, southwest-trending line of outcrops on the western flank of the batholithic Peninsular Ranges in San Diego County (figure 1). Although the Ballena Gravels are only erosional remnants they are up to 110 meters (360 feet) thick, up to 3 kilometers ( 2 miles) wide, and have an outcrop length of 26 


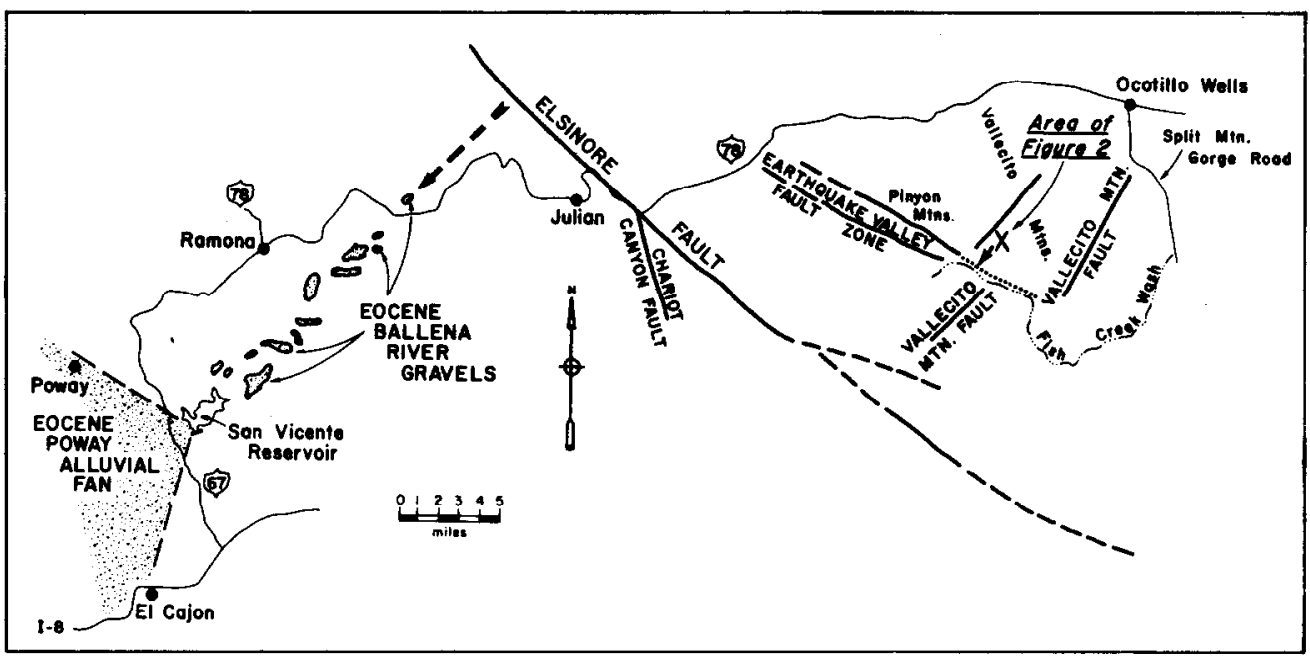

kilometers (16 miles). They have always been interpreted as fluvial deposits because of their linear outcrop subperpendicular to the trend of the Peninsular Ranges, their existence in a low sinuosity paleovalley cut in to the granitic terrane, their abundance of extraregional rhyolite clasts that are rounded and have dominantly prolate shapes, their abundance of percussion-marked quartzite gravels, and their southwestern termination into the apex of a large alluvial fan built out over the coastal plain during Eocene time (Fairbanks, 1893; Minch, 1972, 1979; Steer, 1980). An interesting feature of all Ballena Gravels outcrops is the high percentage of exotic rhyolitic clasts and the relatively low percentage of plutonic clasts derived from the basement rocks into which the river carved its valley (table 1). This dominance of exotic clasts has been attributed to the long distance ( $>300 \mathrm{~km}$ ) of the flow system, which allowed the ultradurable rhyolitic clasts to simply wear down the softer plutonic detritus (Abbott and Peterson, 1978). This interpretation, coupled with the indicators of a semi-arid climate in Middle and Late Eocene time (Peterson and Abbott, 1979), yields a scenario of a longdistance braided stream that flowed seasonally under flash-flood conditions through a granitic terrane of low to moderate relief.

The exotic rhyolite clasts have been subdivided in to four texturally and/or mineralogically unique populations (Kies and Abbott, in press). 1) Poway rhyolite clasts have red, purple, tan or gray colors, are ultradurable, and invariably have sharply defined quartz phenocrysts that, together with white and/or pink feldspar phenocrysts, total about 50 to 70 o/o of the clast. 2) Owl Creek rhyolite clasts have red, purple or gray colors, are not as durable, lack quartz phenocrysts, and their feldspar phenocrysts have indistinct borders and comprise 0 to $30 \mathrm{o} / \mathrm{o}$ of the clast. 3) Las Palmas rhyolite clasts have red, purple, brown or gray colors, are not 
Table 1. Clast populations in eocene conglomerates (In Percents)

\begin{tabular}{|c|c|c|c|c|c|c|c|c|c|}
\hline & \multirow{3}{*}{$\begin{array}{l}\text { MT. } \\
\text { SOLFEDD } \\
\text { FM. } \\
\text { Pacific } \\
\text { Bearch }\end{array}$} & \multirow{3}{*}{$\begin{array}{c}\text { STADIUM } \\
\text { CG } \\
\text { Conrock } \\
\text { Quarry }\end{array}$} & \multirow{3}{*}{$\begin{array}{c}\text { POMERADO } \\
\text { CG } \\
\text { Scripps } \\
\text { Ranch }\end{array}$} & \multicolumn{2}{|c|}{ BALLENA GRAVELS } & \multicolumn{2}{|c|}{ BALLIENA GRAVELLS } & \multirow{2}{*}{\multicolumn{2}{|c|}{$\begin{array}{c}\text { LAS PALM AS GRAVELS } \\
\text { Valle de las Palmas }\end{array}$}} \\
\hline & & & & Mussey & & McCain & Indian & & \\
\hline & & & & Grade & Ramona & Spring & Campsite & Lower & Upper \\
\hline BLACK RHYODACITF. & 26.4 & 1.9 & 6.0 & 0.6 & 1.4 & 0.9 & 0 & 0.6 & 2.0 \\
\hline POWAY & 36.3 & 71.3 & 56.0 & 53.3 & 55.1 & 33.4 & 34.0 & 2.2 & 0 \\
\hline OWL CREEK & 3.4 & 5.9 & 3.8 & 4.8 & 4.0 & 3.7 & 1.9 & 0.8 & 0.9 \\
\hline LAS PALMAS & 0.2 & 2.1 & 4.3 & 9.4 & 5.7 & 9.3 & 11.9 & 56.7 & 58.2 \\
\hline ANDESITE & 10.3 & 9.1 & 13.1 & 12.8 & 19.4 & 13.9 & 4.4 & 8.6 & 9.7 \\
\hline ANDLSITE BRECCIA & 2.2 & 0.4 & 0.7 & 1.8 & 0.6 & 0.9 & - & 1.7 & 3.4 \\
\hline VITROPHERE & - & 1.5 & 1.4 & 0.9 & 0.6 & - & & 2.9 & 1.7 \\
\hline PLUTONIC & 4.1 & 0.4 & 3.1 & 10.5 & 8.0 & 9.3 & 10.7 & 2.0 & 2.3 \\
\hline QUARTZITE & 8.4 & 7.0 & 5.5 & 4.8 & 3.4 & 22.2 & 32.7 & 11.4 & 26.5 \\
\hline GNEISS/SCHIST & 3.8 & 0.2 & 1.0 & 0.3 & 0.3 & 2.8 & 1.9 & 1.7 & 1.0 \\
\hline META. SS/SILTST. & - & & - & - & 0.6 & 1.9 & .. & 1.4 & 0.3 \\
\hline META. CONGL. & $\cdots$ & & $\cdots$ & 0.6 & & - & 0.6 & 0.6 & 1.0 \\
\hline RED X-BED SILTST, & & & - & - & & 0.9 & - & 0.6 & 0.3 \\
\hline MISG. VOLCANIC & 1.7 & 0.4 & 4.3 & 0.3 & 0.9 & - & 1.9 & 2.9 & 0.7 \\
\hline & $n=416$ & $n=529$ & $\mathrm{n}=\mathbf{4 2 0}$ & $n=351$ & $n=350$ & $n=108$ & $\mathrm{n} \equiv 159$ & $n=350$ & $n=290$ \\
\hline
\end{tabular}

as durable as Poway clasts, rarely have quartz phenocrysts with total phenocrysts typically making up 20 to 45 o/o of the rock, and the groundmass texture has a distinctive microporous, microfelted aspect. 4) Black rhyodacite clasts are dark gray to black, may contain quartz and white and/or pink feldspar phenocrysts, and have a characteristic brittle fracture.

The Ballena Gravels have not yielded fossils. They are auriferous as are other Eocene fluvial deposits in California. More importantly, they can be walked out in the field into the alluvial fan-fan delta-paralic system of the San Diego area which has yielded abundant-vertebrate, invertebrate, and microfossil faunas of Middle and Late Eocene age.

The Ballena Gravels outcrops are near the Elsinore fault zone which is one of three major fault zones that constitute the San Andreas fault system in southeastern California; the other two are the San Andreas and the San Jacinto fault zones. Together, these fault zones delineate the present transform boundary between the Pacific and North American lithospheric plates in this region. From its northern end in the northern Peninsular Ranges, the Elsinore fault extends more than 300 kilometers soutwestward toward the short divergent plate boundary underlying the northern Gulf of California (Elders et al., 1972). 


\section{PREVIOUS WORK ON ELSINORE FAULT OFFSET.}

Estimates of the amount of movement on the northern part of the Elsinore fault have indicated as much as 40 kilometers (25 miles) of right slip based on offset facies changes in Paleocene strata (Lamar, 1961; Sage, 1973; Crowell and Ramirez, 1979).

Prior studies along the central and southern parts of the Elsinore fault have produced a range of estimates of displacement. Dibblee (1954) suggested "A great amount of right lateral movement..." Allison (1974) described the splitting of the Elsinore fault zone in the vicinity of the present study area. He determined that 8 kilometers $(5$ miles) of right-lateral displacement had occurred along a southwestern splay (Chariot Canyon fault) of the Elsinore zone and that subparallel faults (e.g. Earthquake Valley fault) to the east may have had comparable offsets. A 4.8 magnitude earthquake in September, 1973, and a series of 36 aftershocks showed that right-lateral slip is presently taking place along the south branch of the Elsinore fault (Allison et al., 1978).

However, other workers have concluded that the offset along the Elsinore fault zone in this study region has been dominantly vertical with a minimal strikeslip component. Weber (1963) suggested an apparent right-lateral offset of about 600 meters $(2,000$ feet $)$ from contact relationship in metamorphic rocks across the fault in the Julian area. Detailed field mapping by Todd (1977) and Todd and Hoggatt (1979) led them to conclude that large-scale lateral displacements have not occurred along the Elsinore fault. In a study of aerial photographs supplemented by field checks, Lowman (1980) stated that there has been little or no strike slip on the Elsinore fault, but that the movement has been primarily dip slip.

\section{BALLENA GRAVELS EAST OF ELSINORE FAULT ZONE.}

The presence of Poway rhyolite clasts in the Pinyon Mountains was reported in an abstract by Sharp (1968). Sharp also stated (pers. comm., 1979) that these rhyolitic gravels might be in Eocene strata or might have been reworked into younger conglomerates. Gordon Gastil (pers. comm., 1980) pointed out an area on the Whale Peak 7.5' topographic quiadrangle northeast of the Pinyon Mountains where he encountered numerous gravels of Poway rhyolite composition.

Our investigations in the areas delimited by Sharp and by Gastil disclosed numerous Poway rhyolite stones as constituents of Neogene conglomerates and as float on modern surfaces that included outcrops of Ballena Gravels as part of their source terrane. However, our fortunes improved when we moved to the southeast into the hills situated north and northeast of McCain Spring on the Harper Canyon $7.5^{\prime}$ topographic quadrangle (figure 2). Here erosional remnants of Eocene 


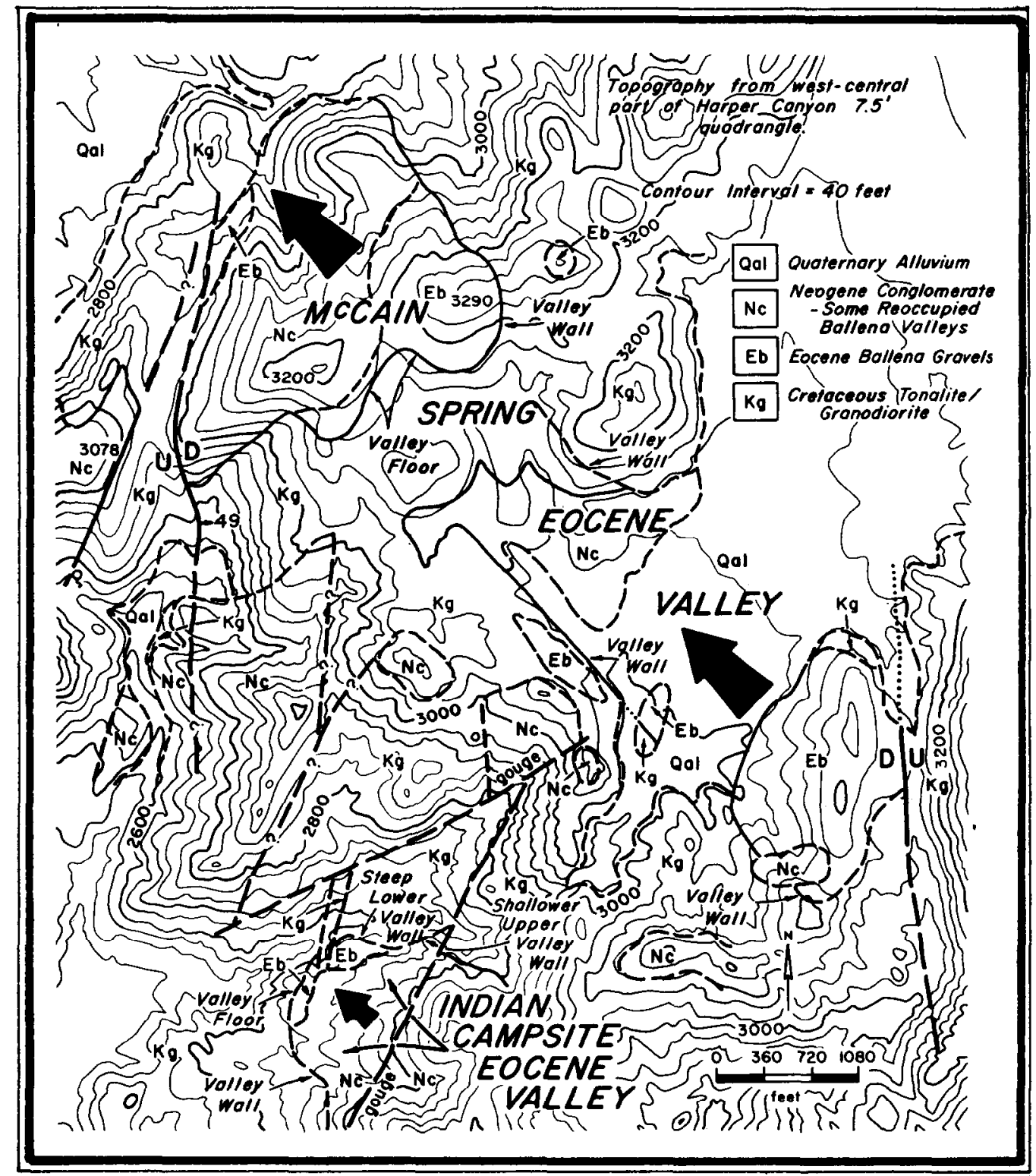

Ballena Gravels lie in valleys carved into the granodiorite and tonalite bedrock. In particular, two northwest-trending paleovalleys, labeled as the Indian Campsite and McCain Spring valleys, are preserved in areas down dropped by faults (figure 2).

The Indian Campsite paleovalley trendsnorthwest, is 335 meters 1,100 
feet) across, and has a cross-valley topographic profile of gently inclined upper valley walls, and a broad flat base. The walls and base of the paleovalley are formed of thoroughly rotted granitic rocks that are markedly more descomposed than granitic exposures away from the old river valley. Above the flat base of the paleovalley (figure 3 ) and abutting the steep walls of the lower paleovalley are coarse conglomerates deposited as lag gravels on the base of the Eocene stream valley. These conglomerates feature extra-regional Poway rhyolite clasts and percussion-marked quartzites up to 67 centimeters in long diametcr. A clast count from the Ballena Gravels is listed in table 1 along with clast populations from other significant localities to be discussed later.

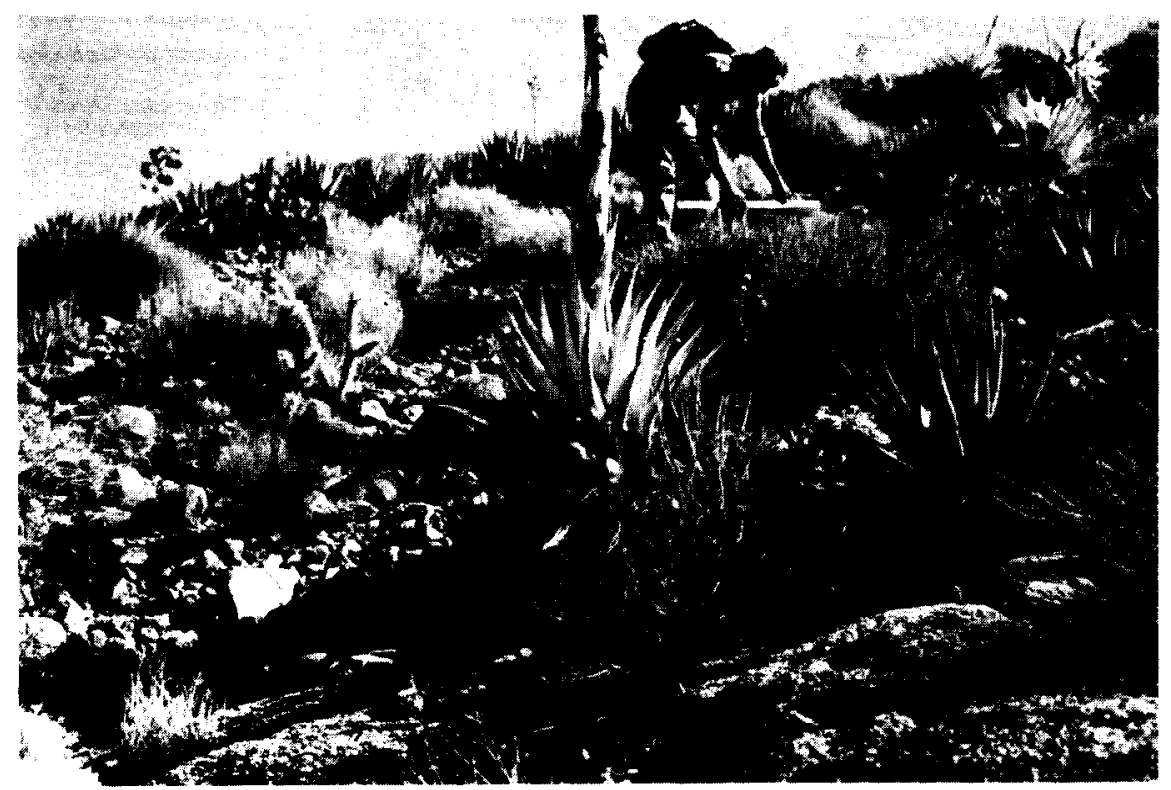

The McCain Spring paleovalley is up to 600 meters (2,000 feet) across and 2,300 meters (7,500 feet) long, is carved into batholithic rocks and also trends northwesterly (figures 2 and 4). One long, well exposed paleovalley wall segment along the southern margin of the McCain Spring paleovalley trends N38 ${ }^{\circ} \mathrm{W}$. The projection of the northwest-trending McCain Spring paleovalley across Harper Flat to the prominent hill on its northern border (on Whale Peak 7.5' topographic map) intersects the slightly undulating base of the same paleovalley carved into the granitic bedrock there. The valley fill in this northwestern continuation is almost totally composed of younger conglomerates deposited by later rivers that reoccupied the Eocene valley. Only one small patch of Ballena Gravels was found here and it was nestled into a protected low spot against the base of a steep lower valley wall segment. 


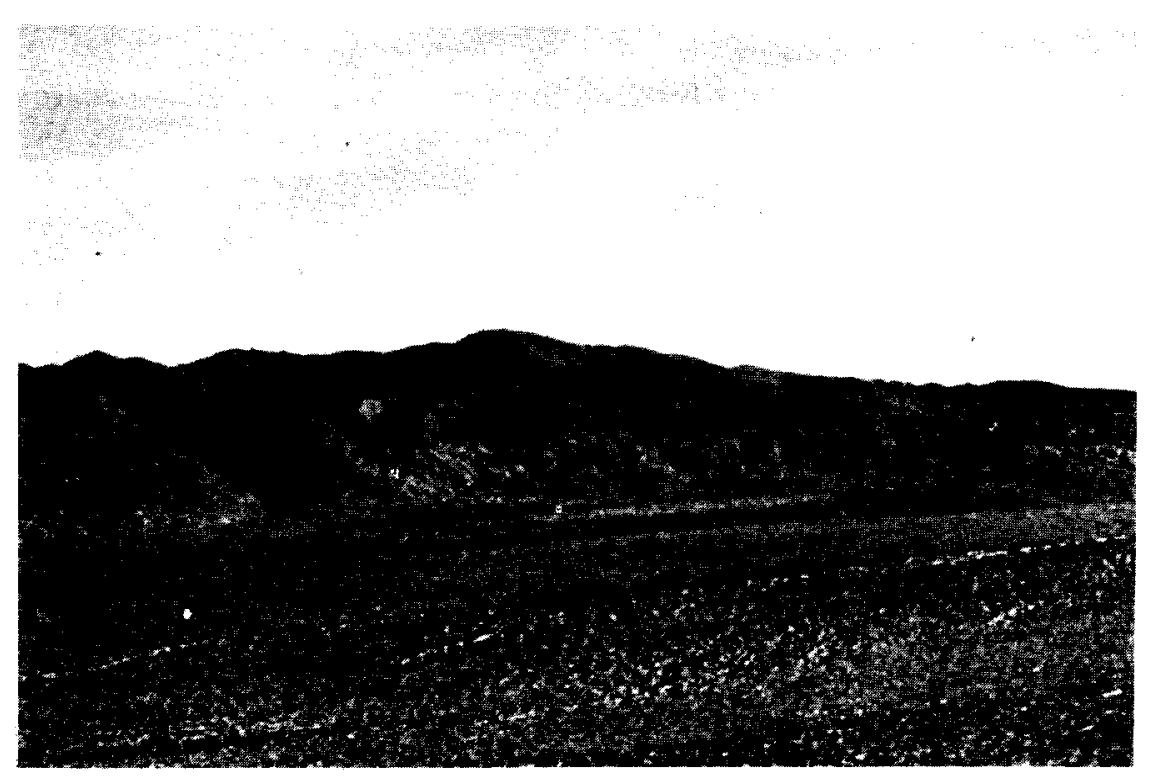

Preserved segments of the McCain Spring paleovalley walls and base expose lags of large Poway rhyolite and quartzite boulders lying on or against rotted plutonic rocks. Gravel specimens include a record long diameter of 84 centimeters measured on a gray Poway rhyolite clast. At the southwestern end of this paleovalley the preserved wall is 54 meters ( 175 feet) high and at the northeastern end, the wall is 160 meters ( 520 feet) high. The paleovalley is filled locally with Eocene Ballena Gravels but also is infilled in its upper parts by younger conglomerates deposited by smaller rivers which reoccupied the Eocene valley. These later streams eroded into the Eocene sedimentary fill and deposited gravels whose clast populations may contain a few percent of reworked Poway rhyolite clasts but are dominated by granitic detritus derived from the surrounding basement terrane.

The Ballena Gravels occur chiefly as float-mantled slopes that also expose lags of unusual clasts let down onto the surface during the erosion of overlying, younger conglomerates. The best exposures are found atop paleovalley floors or against granitic paleovalley walls.

\section{COMPARISON OF CLAST POPULATIONS.}

Poway rhyolite clasts are found in abundance in three Eocene formations of the coastal plain at San Diego (table 1). The Lower-Middle Eocene Mt. Soledad Formation is the oldest of the three units. Thirty-six percent of its conglomerate clasts are Poway rhyolites brought through the Ballena River system 
from distant bedrock exposures to the east (Abbott and Smith, 1978). Twentysix percent of the clasts are members of the distinctive Black Rhyodacite family. These clasts are abundant in Upper Cretaceous conglomerates of San Diego but their percentages dwindle markedly in late Middle Eocene and younger conglomerates.

Comparable Eocene fluvial systems bearing rhyolitic clasts existed to the north in the Los Angeles area (dominated by Owl Creek clast types) and to the south in the Valle de las Palmas area of Baja California (dominated by Las Palmas clast types). Notable but far less abundant are the percentages of clasts from the Owl Creek and Las Palmas rhyolite families.

The Eocene fluvial deposits of the study area have low percentages of Owl Creek and Las Palmas rhyolite clasts; this helps confirm their affinity to the Ballena Gravels.

The Middle-Upper Eocene Stadium Conglomerate is volumetrically the largest of the three San Diego conglomerates and contains the highest percentage of Poway rhyolite clasts $(72 \%)$. At that time, the lengthy Ballena river system apparently was working at maximum efficiency and was disgorging copious quantities of extraregional rhyolite clasts, dominantly of Poway type. Although the Ballena peleovalley is cut into batholithic rocks, the percentage of plutonic detritus dumped onto the alluvial fan-fan delta system was miniscule $(0.4 \mathrm{o} / \mathrm{o})$ due to the ball-mill effect of being tumbled in transport with ultradurable Poway rhyolite clasts.

The Upper Eocene Pomerado Formation is the youngest of the three Eocene conglomerates. Its sedimentation continued until large-scale tectonic and/or climatic changes shut off the long distance braided stream system. In the Pomerado Fm., Poway rhyolite clast percentages are 56 o/o, 16 o/o less than in the Stadium Conglomerate, whereas the percentages of local Peninsular Ranges clasts increase correspondingly. This may be viewed as a harbinger of the impending demise of the Ballena River.

One would intuitively expect the clast population in the Ballena Gravels to most closely approximate the youngest of the coastal-plain alluvial fan systems it supplied. Inspection of table 1 shows a close correspondence in Poway rhyolite clast percentages between the Pomerado Formation and the two unequivocal Ballena river deposits along Mussey Grade and in the southern part of Ramona (56 and 53 to $55 \%$ o respectively). Other variations in clast types all fall within expected statistical variations.

Comparison of the two Ballena Gravels clast populations east of the Elsinore fault with those at Ramona and Mussey Grade shows some differences. Poway rhyolite percentages for the former are lower $(34 \mathrm{o} / \mathrm{o}$ vs. $54 \mathrm{o} / \mathrm{o})$ and 
quartzite percentages are higher $(27 \mathrm{o} / \mathrm{o}$ vs. $4 \mathrm{o} / \mathrm{o})$. The differences may result from scale, i.e., the Ballena paleovalley carved in the batholith near Ramona and Mussey Grade is 1.5 to 3 kilometers ( 1 to 2 miles) wide whereas the paleovalleys incised into plutonic bedrock at McCain Spring and Indian Campsite are 600 and 355 meters (2,000 and 1,100 feet) wide respectively. The latter two paleovalleys may represent incised braided channel segments of the Ballena system in which the percentage of extraregional Poway rhyolite clasts was diluted by resistant quartzite detritus from local, high-grade metamorphic basement rock.

A second possibility is that the McCain Spring and Indian Campsite conglomerates were deposited by southerly tributaries of the Ballena river. However, a southerly source does not seem likely because the clasts are significantly different from the Las Palmas Gravels deposited by the nearest Eocene fluvial system which was subparallel and 60 kilometers (35 miles) to the south (table 1). The Las Palmas Gravels contain on the average only $1.1 \% / 0$ Poway rhyolites and $57.5 \%$ o Las Palmas rhyolites as compared with $33.7 \mathrm{o} / \mathrm{o}$ and $10.6 \mathrm{o} / \mathrm{o}$ for the fault-bounded Ballena Gravels east of the Elsinore fault zone. These differences reinforce the similarity between the Ballena Gravels outcrops west and east of the Elsinore fault.

\section{PIERCING POINT OFFSET.}

The Ballena Gravels outcrop and paleovalley, located near San Diego, trend about $\mathrm{S} 45^{\circ} \mathrm{W}$ over a distance of 25 kilometers $(16$ miles) (Figure 1). The incised paleovalley segments east of the Elsinore and Earthquake Valley faults trend northwest calling for a clockwise tectonic rotation of about $90^{\circ}$. Interestingly enough, paleomagnetic work done by Mace (1981) in the Coyote and Fish Creek Mountains east of the Elsinore fault suggests $88^{\circ}$ to $111^{\circ}$ of clockwise rotation since Early Miocene within this same tectonic block bounded by the Elsinore and San Jacinto fault zones. Removal of this rotation gives similar southwestcrly trends to the Ballena Gravels in the paleovalleys on each side of the Elsinore fault zone. Extrapolation of the trends of the Ballena paleovalleys back to the fault "plane" to create a piercing point suggests a total right-lateral offset of 37 kilometers (23 miles) (Figure 1). Even allowing for some ambiguity in this estimate due to the unknown original location of the Indian Campsite and McCain Spring paleovalleys within the larger Ballena braided river system, the estimated offset still indicates a large amount of right-lateral slip.

In addition, mapping and basin analysis of early Neogene continental rocks in the Split Mountain area (Kerr, 1982) suggest that the Vallecito Mountain fault is a clockwise-rotated, northwest translated, Miocene Basin-and-Range normal fault. Right-lateral offset of the Vallecito Mountain fault (figure 1) suggests about 5.6 kilometers (3.5 miles) of slip on the Earthquake Valley fault, a branch of the Elsinore fault zone. This in turn suggests about 31.5 kilometers (19.5 miles) of right slip on the other branches of the Elsinore fault zone. 


\section{ACKNOWLEDGMENTS}

We would like to thank Gordon Gastil and Robert Sharp for directing us to this region of Poway rhyolite clasts east of the Elsinore fault. The manuscript was improved through reviews by Victoria Todd, Art Sylvester, and Gordon Gastil. We also appreciate the translation of the abstract in to Spanish by Eugenia Sangines.

\section{REFERENCES}

ABBOTT, P.L. y G.L. Peterson. 1978. Effects of abrasion durability on conglomerate clast populations: examples from Cretaceous and Focene conglomerates of the San Diego area, California: Journal of Sedimentary Petro$\operatorname{logy}, 48: 31-42$.

ABBOTT, P.L. y T.E. Smith. 1978. Trace-element comparison of clasts in Eocene conglomerates, southwestern California and northwestern Mexico: Journal of Geology, 86: 753-762.

ALLISON, M.L. 1974. Geophysical studies along the southern portion of the Elsinore fault. M. S. thesis. San Diego State University, 229 p.

ALLISON, M.L., J.H. Whitcomb. G.E. Cheatum, y R.B. McEuen. 1978. Elsinore fault seismicity: the September 13, 1973, Agua Caliente Springs, California, carthquakc scrics. Scismological Socicty of Amcrica Bulletin, 68: 429-440.

CROWELL, J.C. y V.R. Ramírez. 1979. Late Cenozoic faults in southeastern California. In: Tectonics of the Juncture Between the San Andreas Fault System and the Salton Troug, Southeastern California. Crowell, J.C. and Sylvester, A.G., (Eds.). University of California, Santa Barbara, Guidebook, 27-40.

DIBBLEE, T.W., Jr. 1954. Geology of the Imperial Valley region, California. In: Geology of Southern California: Jahns, R.H., (Ed.). California Division of Mines, Bulletin 170: 21-28.

ELDERS, W.A., R.W. Rex, T. Meidev, P.T. Robinson, y S. Biehler. 1972. Crustal spreading in southern California. Science, 178: 15-24.

FAIRBANKS, H.W. 1893. Geology of San Diego; also portions of Orange and San Bernardino Counties. California State Mining Bureau 11th Annual Report, 76-120.

KERR, D.R. 1982. Early Neogene sedimentation, western Salton Trough, California. M.S. thesis. San Diego State University. 
KIES, R.P. 1982. Paleogene sedimentology and lithostratigraphic correlations;San Miguel Island, Santa Cruz Island and coastal San Diego, California. M.S. thesis. San Diego State University, 510 p.

KIES, R.P. y P.L. Abbott. 1983. Rhyolite Clast Populations and Tectonics in the California Continental Borderland: Journal of Sedimentary Petrology (in press).

LAMAR, D.L. 1961. Structural evolution of the northern margin of the Los Angeles basin. Ph. D. dissertation. Univ. California, Los Angeles, 142 p.

LOWMAN, P.D., Jr. 1980. Vertical displacement on the Elsinore fault of southern California: Evidence from orbital photographs. Journal of Geology, 88: 415-432.

MACE, N. 1981. Paleomagnetic study of the Miocene Alverson Volcanics of the Coyote Mountains, western Salton Trough, California. M.S. thesis. San Diego State University.

MINCH, J.A. 1972. The Late Mesozoic-Early Tertiary framework of continental sedimentation, northern Peninsular Ranges, Baja California, Mexico. Ph.D. dissertation. University of California, Riverside, $192 \mathrm{p}$.

1979. The Late Mesozoic-Early Tertiary framework of continental sedimentation, northern Peninsular Ranges, Baja California, Mexico. In: Eocene Depositional Systems, San Diego, California. Abbott, P.L., (Ed.). Society of Economic Paleontologists and Mineralogists, Pacific Section, GUIDEBOK, 43-68.

PETERSON, G.L. y P.L. Abbott. 1979. Mid-Eocene climatic change, south western California and northwestern Baja California. Palaeogeography, Palaeoclimatology, Palaeoecology, 26: 73-87.

SAGE, O.G., Jr. 1973. Paleocene geography of southern California. Ph.D.dissertation. University of California, Santa Barbara, $250 \mathrm{p}$.

SHARP,R.V.1968. The San Andreas fault system and contrasting pre-San Andreas structures in the Peninsular Ranges of southem California. In: Proceedings of Conference on Geologic Problems of San Andreas fault system. Dickinson, W.R. and A. Grantz (Eds.). Stanford University Publication, Geological Sciences, XI: 292-293.

STEER, B.L. 1980. Paleohydrology of the Eocene Ballena Gravels, San Diego, California. M.S. thesis. San Diego State University, 147 p. 
TOOD. V.R. 1977. Geologic map of Agua Caliente Hot Springs quadrangle, San Diego County, California. U.S. Geological Survey Open File Report 77-742, $20 \mathrm{p}$.

TOOD, V.R. y W.C. Hoggatt. 1979. Vertical tectonics of the Elsinore fault zone south of $33^{\circ} 7^{\prime} 30^{\prime \prime}$. Geological Society of America Abstracts, 11:528.

WEBER, F.H. 1963. Geology and mineral resources of San Diego County, Califormia. California Division of Mines and Geology, County Report 3, 309 p. 